IJTC

Ilomata International Journal of Tax \& Accounting

P-ISSN: 2714-9838; E-ISSN: 2714-9846

https://www.ilomata.org/index.php/ijtc

\title{
The Effect of Return on Asset (ROA), Debt to Equity Ratio (DER), Earning per Share (EPS), Total Asset Turnover (TATO) and Exchange Rate on Stock Return of Property and Real Estate Companies at Indonesia Stock Exchange Period 2012-2017
}

\author{
Fakhri Rana Sausan, Lardin Korawijayanti, , Arum Febriyanti Ciptaningtias \\ Program Studi Akuntansi Manajerial Jurusan Akuntansi Politeknik Negeri Semarang \\ lardinkorawijayanti@polines.ac.id
}

Submitted : Dec 12 2019 Revised $\quad$ : Jan 31th $2020 \quad$ Published $\quad$ March 30 th 2020

\begin{abstract}
This research aims to analyze the effect of Return On Asset (ROA), Debt to Equity Ratio (DER), Earning Per Share (EPS), Total Asset Turnover (TATO) and Exchange Rate on Stock Return of Property and Real Estate Companies at Indonesia Stock Exchange period 2012-2017. The sample of this research is consists of 21 property and real estate companies with 6 years period so a total of sample is 126 samples. Sources data is secondary data. The data analysis method in this research is used Multiple Linear Regression. The result shows that Debt to Equity Ratio (DER), Total Asset Turnover (TATO) and Exchange rate of Rupiah/US Dollar partially has got a significant effect on stock return while Return On Asset (ROA) and Earning Per Share (EPS) partially has got an insignificant effect on stock return, its mean Return On Asset (ROA) and Earning Per Share (EPS) can't be determinant of stock return to investors who want to invest in the capital market.
\end{abstract}

Keywords: Return On Asset (ROA), Debt to Equity Ratio (DER), Earning Per Share (EPS), Total Asset Turnover (TATO), Exchange rate and Stock Return.

\section{INTRODUCTION}

The capital market can be interpreted as a vehicle that brings together those who need funds with those who provide funds, in accordance with the rules established by institutions and professions related to securities. Law No. 8 of 1995 concerning the Capital Market has outlined that the capital market has a strategic position in national economic development. From the economic point of view the capital market has a function as a long-term fund mobility for the government, because through the capital market the government can allocate funds to the public through potential and profitable sectors.

Investment activities are activities that place funds in one or more assets during a certain period in the hope of earning income / profits or an increase in the value of the initial investment (capital) that aims to maximize returns (future). In investing in the capital market analysts and investors can take an investment approach that can be broadly divided into two namely technical analysis and fundamental analysis (Tandelilin, 2010 in Amor Marundha, 2014).

According to Suad Husnan (2005: 358) that Technical Analysis is an attempt to estimate stock prices and market conditions by observing changes in the stock price (market conditions) in the past. Meanwhile, according to Ang (1997) that technical analysis is a study conducted to 
The Effect Of Return On Asset (ROA), Debt To Equity Ratio (DER), Earning Per Share (EPS), Total Asset Turnover (TATO) And Exchange Rate On Stock Return Of Property And Real Estate Companies At Indonesia Stock Exchange Period 2012-2017

Sausan, Korawijayanti, Ciptaningtias

study various influential forces on the stock market and the implications that this has on stock prices. According Jogiyanto (2014: 189) fundamental analysis is an analysis to calculate the intrinsic value of a stock using corporate financial data. Fundamental analysis looks at the development of financial ratios in terms of solvency, liquidity, profitability and corporate financial policy in investing and financing. In addition, the development of performance and dividend policy complements fundamental analysis(Rulandari et al., 2018; Sofyan, 2016).

The good financial performance of a company is a major consideration for investors. The better the level of financial performance of a company is expected to increase stock prices and will provide profits (return) for investors, because stock returns are the difference between current stock prices and previous stock prices. High stock return is one of the attractions for investors to invest their funds in the capital market. Thus, if the company's ability to generate profits increases, the share price will also increase. The higher the return or profit obtained, the better the position of the owner of the company (Suad Husnan, 2001 in Defrizal 2015).

The presence of the capital market in Indonesia is marked by the number of investors who have begun to invest in the property and real estate industry. The property and real estate business, both residential and commercial, have shown quite rapid development in Indonesia, as evidenced by the increasingly widespread development housing, business center and supermall in the last years. The rapid development of the property sector is followed by the higher demand for boards, so property companies need funds from external sources. Many people invest their capital in the property industry because land prices tend to rise. The reason is that the land supply is fixed while demand will always be large as population grows. Head of the Central Statistics Agency Suhariyanto said that the highest improvement in business conditions is expected to occur in the real estate business field with an ITB value of 111.20 (SindoNews.com, 2017).

The stock price has increased and decreased which is influenced by various factors. These factors are macroeconomic factors and fundamental factors. Macroeconomic factors stem from broad economic problems, for example economic policy, inflation, interest rates, currency exchange rates, public income and others. Fundamental factors are factors originating from within the company that issued the shares themselves (the issuer). If a company that issues shares is in good condition, its stock price will tend to increase and if the stock price increases, the return it receives will also increase. This is because investor confidence in the issuer is getting better, investors have the expectation of getting a large share of profits or dividends. This fundamental factor can be seen from financial statements. The issuer's financial statements can be seen the level of financial performance both in terms of ability to generate profits (profitability), ability to pay debts (solvency), as well as the level of efficiency and effectiveness in managing their wealth (activities).

Problems in this study arise because of the research gap that shows the results of different studies regarding the related variables in this study. Previous research that became a reference in this study is a study conducted by Agung Tri Atidhira and Andi Ina Yustina (2017) by adding 2 other variables, namely Total Asset Turnover (TATO) and Rupiah Exchange Rates to the US Dollar. This study uses property and real estate companies as research objects starting from 2012-2017. The reason researchers chose this company is because the property and real estate companies have bright prospects in the future by seeing the potential population continues to grow and the increasing number of developments in the housing sector, apartments, shopping 
The Effect Of Return On Asset (ROA), Debt To Equity Ratio (DER), Earning Per Share (EPS), Total Asset Turnover (TATO) And Exchange Rate On Stock Return Of Property And Real Estate Companies At Indonesia Stock Exchange Period 2012-2017

Sausan, Korawijayanti, Ciptaningtias

centers, and office buildings that attract investors to invest their funds so that the prospect of stock trading is expected to continue to increase.

\section{METHOD}

The type of data used in this study is secondary data that is data obtained from other parties in the form of data that is ready to be processed or published. Secondary data refers to information collected by a person, and not to a researcher who is carrying out a sophisticated study. The data can be internal or external to the organization and accessed through the internet, document searches, or publication of information (Now, 2006: 65). These data include quantitative data because in their calculations use numbers (nominal) and are a type of panel data (pooled data), that is data that uses multiple objects (cross section) in several research periods (time series) based on a summary of January's performance 2012 - December 2017 in property and real estate companies. In this study, the data used are secondary data including Return On Assets (ROA), Debt to Equity Ratio (DER), Earning per Share (EPS) and Total Asset Turnover (TATO) derived from the financial statements of sample companies obtained from the Stock Exchange Indonesian Securities through its official website, namely www.idx.co.id and US dollar exchange rate data obtained from Bank Indonesia (BI) through its official website, namely www.bi.go.id. Specifically Stock Return data is obtained by processing stock closing price data from the Indonesian Capital Market Directory (ICMD) or the site http://finance.yahoo.com.

The population in this study were 57 (fifty seven) property and real estate companies listed on the Indonesia Stock Exchange (IDX) and published their data in the Indonesian Capital Market Directory (ICMD). Based on the Purposive Sampling technique, 21 (twenty one) companies were obtained in the property and real estate sector that met the requirements and were suitable for use as research samples.

There are two variables used in this study, namely the independent variable $(\mathrm{X})$ and the dependent variable $(\mathrm{Y})$. The independent variable $(\mathrm{X})$ consists of Return On Assets (ROA), Debt to Equity Ratio (DER), Earning per Share (EPS), Total Asset Turnover (TATO) and Rupiah / US Dollar Exchange Rate, while the dependent variable (Y) is Return Stock.

Data analysis method used in this study is multiple linear regression analysis used to test the effect of two or more independent variables on one dependent variable (Imam, 2013: 13). other than that Classic assumption tests are also used to test whether the regression model really shows a significant and representative relationship consisting of: Autocorrelation Test, Normality Test, Multicollinearity Test, and Heterokedasticity Test; and Determination Testing and Hypothesis Testing consisting of the $\mathrm{F}$ test and $\mathrm{t}$ test. The $\mathrm{F}$ test is used to determine the effect of the independent variables on the dependent variable simultaneously. $T$ test is used to determine the effect of the independent variable partially on the dependent variable.

\section{RESULT AND DISCUSSION}

The results of the multiple regression test in this study are as follows:

Multiple Linear Regression Test Results 
The Effect Of Return On Asset (ROA), Debt To Equity Ratio (DER), Earning Per Share (EPS), Total Asset Turnover (TATO) And Exchange Rate On Stock Return Of Property And Real Estate Companies At Indonesia Stock Exchange Period 2012-2017

Sausan, Korawijayanti, Ciptaningtias

Coefficients $^{\mathrm{a}}$

\begin{tabular}{|c|c|c|c|c|c|c|}
\hline \multirow{2}{*}{\multicolumn{2}{|c|}{ Model }} & \multicolumn{2}{|c|}{ Unstandardized Coefficients } & \multirow{2}{*}{$\begin{array}{c}\begin{array}{c}\text { Standardized } \\
\text { Coefficients }\end{array} \\
\text { Beta }\end{array}$} & \multirow[b]{2}{*}{$t$} & \multirow[b]{2}{*}{ Sig. } \\
\hline & & $B$ & Std. Error & & & \\
\hline \multirow[t]{6}{*}{1} & (Constant) & 86.290 & 29.517 & & 2.923 & .004 \\
\hline & ROA & -.173 & .800 & -.025 & -.217 & .829 \\
\hline & DER & -16.697 & 7.601 & -.205 & -2.197 & .030 \\
\hline & EPS & .013 & .016 & .081 & .821 & .413 \\
\hline & TATO & 111.972 & 52.702 & .253 & 2.125 & .036 \\
\hline & KURS & -.007 & .002 & -.260 & -3.094 & .002 \\
\hline
\end{tabular}

a. Dependent Variable: RETURN SAHAM

Source: Secondary data processed.

Based on the test results with multiple linear regression methods, then an equation can be arranged as follows:

Stock Return $=86,290-$ 0,173 $($ ROA $)-16,697($ DER $)+$ 0,013 (EPS) + 111,972 (TATO) - 0,007 (KURS)

The regression equation can be described as follows:

a. $\quad \alpha=86.290$ means that if the value of other variables equal zero, then the value of stock returns is 86.290 .

b. $\quad \mathrm{X} 1=-0.173$ means that for every $1 \%$ increase in ROA, stock returns will decrease by 0.173 assuming the other variables are constant.

c. $\quad \mathrm{X} 2=-16,697$ means that every 1 time increase in DER, the stock return will decrease by 16,697 assuming the other variables are constant.

d. $\quad \mathrm{X} 3=0.013$ means that for every increase of Rp 1 EPS, the stock return will increase by 0.013 assuming the other variables are constant.

e. $\quad \mathrm{X} 4=111,972$ means that every 1 times increase in TATO, then stock returns will increase by 111,972 assuming the other variables are constant.

f. $\quad \mathrm{X} 5=-0.007$ means that for every increase of IDR 1 KURS, the stock return will decrease by 0.007 assuming the other variables are constant.

Determination Coefficient Test Results (R2)

Model Summary

\begin{tabular}{|l|l|l|r|r|}
\hline Model & $\mathrm{R}$ & $\mathrm{R}$ Square & \multicolumn{1}{c|}{$\begin{array}{c}\text { Adjusted R } \\
\text { Square }\end{array}$} & $\begin{array}{c}\text { Std. Error of } \\
\text { the Estimate }\end{array}$ \\
\hline 1 & $.406^{\mathrm{a}}$ & .165 & .130 & $40.07917 \%$ \\
\hline
\end{tabular}

a. Predictors: (Constant), KURS, ROA, DER, EPS, TATO

Source: Secondary data processed.

Based on the results of the coefficient of determination (R2) test, it is known that the value of $R$ Square in the sample companies is 0.165 while the adjusted $\mathrm{R}$ square value is 0.130 or $13 \%$. Thus it can be concluded that the magnitude of the effect of Return On Assets (ROA), Debt To Equity Ratio (DER), Earning Per Share (EPS), Total Asset Turnover (TATO) and Rupiah 
The Effect Of Return On Asset (ROA), Debt To Equity Ratio (DER), Earning Per Share (EPS), Total Asset Turnover (TATO) And Exchange Rate On Stock Return Of Property And Real Estate Companies At Indonesia Stock Exchange Period 2012-2017

Sausan, Korawijayanti, Ciptaningtias

Exchange Rate on stock returns is $13 \%$ while the remaining $87 \%$ is influenced by other variables outside the study.

Anova F (Simultaneous) Test Results

\begin{tabular}{|c|c|c|c|c|c|c|}
\hline \multicolumn{7}{|c|}{ ANOVA $^{\circ}$} \\
\hline & & $\begin{array}{l}\text { Sum of } \\
\text { Squares }\end{array}$ & df & Mean Square & $\mathrm{F}$ & Sig. \\
\hline \multirow[t]{3}{*}{1} & Regression & 37960.229 & 5 & 7592.046 & 4.726 & $.001^{\mathrm{a}}$ \\
\hline & Residual & 192760.796 & 120 & 1606.340 & & \\
\hline & Total & 230721.024 & 125 & & & \\
\hline
\end{tabular}

Source: Secondary data processed.

Based on the results of the $f$ test above it can be seen that the Fcount value was 4.726 and the significance value was 0.001 . It can be seen that the value of Fcount 4.726 is greater than F table. Ftable is determined by reading table $\mathrm{F}$, with the number of independent variables of 5 (five) variables $(\mathrm{k}=5)$ and the number of samples of 126 , with a degree of freedom $(\mathrm{df})$ of $\mathrm{df}=(\mathrm{nk})$ that is equal to 121, so it can be determined Ftable of 2.29. The significance value of 0.001 is less than the significance level of $0.05(\alpha=0.05)$ and Fcount is greater than Ftable, then Ho is rejected and $\mathrm{Ha}$ is accepted. This shows that the independent variables namely Return $\mathrm{On}$ Assets (ROA), Debt To Equity Ratio (DER), Earning Per Share (EPS), Total Asset Turnover (TATO) and Rupiah Exchange Rates simultaneously or jointly able to explain changes in variables The dependent is stock returns, so it can be concluded that Return On Assets (ROA), Debt To Equity Ratio (DER), Earning Per Share (EPS), Total Asset Turnover (TATO) and Rupiah Exchange Rates simultaneously affect stock returns. 
The Effect Of Return On Asset (ROA), Debt To Equity Ratio (DER), Earning Per Share (EPS), Total Asset Turnover (TATO) And Exchange Rate On Stock Return Of Property And Real Estate Companies At Indonesia Stock Exchange Period 2012-2017

Sausan, Korawijayanti, Ciptaningtias

T Test Results (Partial Test)

\begin{tabular}{|c|c|c|c|c|c|c|}
\hline \multicolumn{7}{|c|}{ Coefficients $^{a}$} \\
\hline \multirow{2}{*}{\multicolumn{2}{|c|}{ Model }} & \multicolumn{2}{|c|}{ Unstandardized Coefficients } & \multirow{2}{*}{$\begin{array}{c}\text { Standardized } \\
\text { Coefficients } \\
\text { Beta }\end{array}$} & \multirow[b]{2}{*}{$t$} & \multirow[b]{2}{*}{ Sig. } \\
\hline & & $B$ & Std. Error & & & \\
\hline \multirow[t]{6}{*}{1} & (Constant) & 86.290 & 29.517 & & 2.923 & .004 \\
\hline & ROA & -.173 & .800 & -.025 & -.217 & .829 \\
\hline & DER & -16.697 & 7.601 & -.205 & -2.197 & .030 \\
\hline & EPS & .013 & .016 & .081 & .821 & .413 \\
\hline & TATO & 111.972 & 52.702 & .253 & 2.125 & .036 \\
\hline & KURS & -.007 & .002 & -.260 & -3.094 & .002 \\
\hline
\end{tabular}

a. Dependent Variable: RETURN SAHAM

Source: Secondary data processed.

Based on the results of the $t$ test above, it can be seen that Debt To Equity Ratio (DER), Total Asset Turnover (TATO) and Rupiah Exchange Rate partially have a significant effect on Stock Returns because they have a significance value of more than 0.05 or $5 \%$ significance level, whereas Return On Asset (ROA) and Earning Per Share (EPS) partially have no significant effect on Stock Return because the significance value is less than the significant level of 0.05 or $5 \%$.

Effect of Return On Assets (ROA) on Stock Return.

Return On Assets (ROA) as one of the independent variables that do not have a significant effect on stock returns as the dependent variable. Based on the results of the multiple linear regression model equation, it is known that the ROA value of -0.173 means that if ROA increases by $1 \%$ then stock returns will decrease by 0.173 . Return On Assets (ROA) shows the result of $t$ count of -0.217 , where $t$ arithmetic is greater than $t$ table that is equal to -1.97976 . Besides being seen from $t$ arithmetic can also be seen from the significance of Return on Assets (ROA) of 0.829 . This value above the significance level of 0.05 indicates that Return On Assets (ROA) has no significant effect on stock returns on property and real estate companies listed on the Indonesia Stock Exchange (IDX). This research shows that a high ROA does not really attract investors in the capital market. This shows that the good profitability performance of the company can really be seen when investors also consider other profitability ratios such as Gross Profit Margin (GPM), Net Profit Margin (NPM), Return On Equity (ROE), and Operating Ratio. So, ROA itself is difficult to attract investors to buy company shares if other profitability ratios have different conditions. With the increase in ROA from the previous period, that does not mean that economic conditions are good. Poor economic conditions can also cause a decrease in stock returns despite increased ROA. The research period for 6 (six) years from 2012 to 2017 property and real estate companies experienced fluctuations. This shows that companies with fluctuating Return On Assets (ROA) do not have the potential to attract investors to invest their shares. This condition makes the company's stock price increase so that Return on Assets (ROA) that experience fluctuations will not affect the company's stock return. In this research, Return On Assets (ROA) cannot be used as a basis for determining stock returns. 
The Effect Of Return On Asset (ROA), Debt To Equity Ratio (DER), Earning Per Share (EPS), Total Asset Turnover (TATO) And Exchange Rate On Stock Return Of Property And Real Estate Companies At Indonesia Stock Exchange Period 2012-2017

Sausan, Korawijayanti, Ciptaningtias

The results of this test are supported by previous research conducted by Agung Tri (2017) and Farda Eka (2016), which in his research concluded that Return on Assets (ROA) had no significant effect on stock returns.

Effect of Debt To Equity Ratio (DER) on Stock Returns. Debt To Equity Ratio (DER) as one of the independent variables that has a significant effect on stock returns as the dependent variable. Based on the results of the multiple linear regression model equation, it is known that the DER value is $-16,697$ which means that if the DER increases once, the stock return will decrease by 16,697. Debt To Equity Ratio (DER) shows the result of $t$ count of -2.197 , where $t$ count is smaller than $t$ table of -1.97976 . In addition to the $t$ count, it can also be seen from the significance of the Debt To Equity Ratio (DER) of 0.030. This value is below the significance level of 0.05 , indicating that Debt To Equity Ratio (DER) has a significant effect on stock returns on property and real estate companies listed on the Indonesia Stock Exchange (IDX). In this study it can be interpreted that Debt To Equity Ratio (DER) can be used as a basis for determining stock returns. Debt To Equity Ratio (DER) measures how far property and real estate companies are financed by debt. This debt arises because not all company needs can be met by the company's own capital. Debt to Equity Ratio (DER) ratio calculation of property and real estate companies has a fairly high DER value. The higher the DER reflects the relatively high risk of the company, consequently reducing the interest of investors to invest in companies that have a high Debt to Equity Ratio (DER). If there are no investors who are interested to invest, it will have an impact on the decline in the company's stock price and will affect the stock return.

The results of this test are supported by previous research conducted by Ni Kadek Raningsih (2015) and Ihsan S. Basalama et al. (2017), in which his research concluded that Debt to Equity Ratio (DER) had a significant effect on stock returns.

Effect of Earning Per Share (EPS) on Stock Return. Earning Per Share (EPS) as one of the independent variables that does not have a significant effect on stock returns as the dependent variable. Based on the results of the equation of the multiple linear regression model, it is known that the EPS value of 0.013 , which means that if EPS increases by Rp 1, stock returns will increase by 0.013. Earning Per Share (EPS) shows the result of tcount of 0.821, where $t$ arithmetic is smaller than $\mathrm{t}$ table of 1.97976. Besides seen from $\mathrm{t}$ arithmetic can also be seen from the significance of Earning Per Share (EPS) of 0.413. This value above the significance level of 0.05 indicates that Earning Per Share (EPS) has no significant effect on stock returns on property and real estate companies listed on the Indonesia Stock Exchange (IDX). This is due to fluctuations in earnings per share (EPS). Property and real estate companies have fluctuating EPS which causes the company in generating net profit after tax to experience instability. This indicates that a declining EPS indicates that investors no longer want to invest their shares in the company. As a result, company profits will decline, so that EPS does not affect stock prices. The absence of influence on the stock price will also affect the company's stock return. This insignificant result, it can be concluded that the EPS variable cannot be used as a reference in determining the investment strategies of investors in investing their shares in the capital market in the study period. 
The Effect Of Return On Asset (ROA), Debt To Equity Ratio (DER), Earning Per Share (EPS), Total Asset Turnover (TATO) And Exchange Rate On Stock Return Of Property And Real Estate Companies At Indonesia Stock Exchange Period 2012-2017

Sausan, Korawijayanti, Ciptaningtias

The results of this test are supported by previous research conducted by Ferdinan Eka (2016) and Verawaty et al. (2015), in which his research concluded that Earning Per Share (EPS) had no significant effect on stock returns.

Effect of Total Asset Turnover (TATO) on Stock Returns. Total Asset Turnover (TATO) as one of the independent variables that has a significant effect on stock returns as the dependent variable. Based on the results of the equation of the multiple linear regression model, it is known that the TATO value is 111.972 which means that if TATO increases 1 time the stock return will increase 111.972. Total Asset Turnover (TATO) shows the result of tcount of 2.125, where $t$ arithmetic is greater than $\mathrm{t}$ table of 1.97976. In addition to the $\mathrm{t}$ count can also be seen from the significance of the Total Asset Turnover (TATO) of 0.036. This value is below the significance level of 0.05 indicating that the Total Asset Turnover (TATO) has a significant effect on stock returns on property and real estate companies listed on the Indonesia Stock Exchange (IDX). In this study it can be interpreted that the Total Asset Turnover (TATO) can be used as a basis for determining stock returns. The level of Total Asset Turnover (TATO) owned by property and real estate companies in supporting sales activities can explain the stock returns received by investors. The company's ability to optimize all its assets effectively and efficiently can bring in revenue for the company, so that it can attract investors to buy the company's shares. If many investors invest their shares, the company's stock price will increase, so the company's stock returns received by investors will also increase.

The results of this test are supported by previous research conducted by Tantri Bararoh (2015) which concluded that Total Assets Turnover (TATO) has a significant effect on stock returns.

Effect of Rupiah Exchange Rates on Stock Returns. Rupiah Exchange Rate as one of the independent variables that has a significant influence on stock returns as the dependent variable. Rupiah Exchange Rate shows the t-value of -3.094, where the t-count is smaller than t-table of 1.97976. Aside from looking at $\mathrm{t}$ arithmetic can also be seen from the significance of the Rupiah Exchange Rate of 0.002. This value is below the significance level of 0.05 indicating that the Rupiah Exchange Rate has a significant effect on stock returns on property and real estate companies listed on the Indonesia Stock Exchange (IDX). In this study it can be interpreted that the Rupiah Exchange Rate can be used as a basis for determining stock returns. Based on the results of the multiple regression equation model, it is known that the exchange rate of the rupiah (exchange rate) of -0.007 , which means that if the exchange rate increases $\mathrm{Rp} 1$, the company's stock return will decrease by 0.007 and investors will not reinvest their shares in the company which will cause the stock price to also decrease, if the share price decreases, stock returns that will be received by investors will also decrease. Besides the weakening of the rupiah against the US dollar can affect stock returns to be received by investors.

The results of this test are supported by previous research conducted by Ariyani Indriastuti (2017) and Ni Kadek Suriyani (2018), which in his research concluded that the Rupiah Exchange Rate (Exchange Rate) has a significant effect on stock returns.

Effects of Return On Assets (ROA), Debt To Equity Ratio (DER), Earning Per Share (EPS), Total Asset Turnover (TATO) and Rupiah Exchange Rates on Stock Returns 
The Effect Of Return On Asset (ROA), Debt To Equity Ratio (DER), Earning Per Share (EPS), Total Asset Turnover (TATO) And Exchange Rate On Stock Return Of Property And Real Estate Companies At Indonesia Stock Exchange Period 2012-2017

Sausan, Korawijayanti, Ciptaningtias

Return On Assets (ROA), Debt To Equity Ratio (DER), Earning Per Share (EPS), Total Asset Turnover (TATO) and Rupiah Exchange Rate have an influence on stock returns. These results can be seen Fcount value of 4.726 and a significance value of 0.001 . It can be seen that the calculated $F$ value of 4.726 is greater than the F table of 2.29 and the significance value is below the significance level of 0.05. This states that Return On Assets (ROA), Debt To Equity Ratio (DER), Earning Per Share (EPS), Total Asset Turnover (TATO) and Rupiah Exchange Rates simultaneously affect stock returns.

The coefficient of determination (R2) is known that the value of R Square in the sample companies is 0.165 while the adjusted $\mathrm{R}$ square value is 0.130 or $13 \%$. Thus it can be concluded that the magnitude of the effect of Return On Assets (ROA), Debt To Equity Ratio (DER), Earning Per Share (EPS), Total Asset Turnover (TATO) and Rupiah Exchange Rate on stock returns is $13 \%$ while the remaining $87 \%$ is influenced by other variables outside the study. Other variables outside this study that might have a major influence on stock returns are Net Profit Margin (NPM), Current Ratio (CR), Price to Book Value (PBV), Inflation and Interest rates. This is supported by the results of research conducted by Anistia Nurhakim (2016) and Ferdinan Eka (2016) stating that Net Profit Margin (NPM) affects stock returns. Research conducted by Farda Eka (2016) states that Current Ratio (CR) has a significant effect on stock returns. Research conducted by Lardin Korawijayanti (2014) states that Price to Book Value (PBV) has a significant effect on stock returns. Research conducted by Sri Suyati (2015) states that inflation and interest rates have a significant effect on stock returns.

\section{CONCLUSION}

a. Return on Assets (ROA) partially does not significantly influence the return of shares of property and real estate companies listed on the Indonesia Stock Exchange in 2012 to 2017. Conditions of Return on Assets (ROA) of property and real estate companies that experience fluctuations do not have the potential for power attract investors to invest their shares. This can make the company's stock price increase so that fluctuating Return on Assets (ROA) will not affect the company's stock return

b. Debt To Equity Ratio (DER) partially has a significant effect on the stock returns of property and real estate companies listed on the Indonesia Stock Exchange in 2012 to 2017. Property and real estate companies have a high DER value, so the risk borne by the company is also relatively high. This can reduce the company's stock returns and reduce investor interest in investing in the company.

c. Earning Per Share (EPS) partially has no significant effect on stock returns of property and real estate companies listed on the Indonesia Stock Exchange in 2012 to 2017. The results of this study indicate that Earning Per Share (EPS) cannot be used as a basis for determining stock returns. Property and real estate companies have fluctuating EPS which causes the company in generating net profit after tax to experience instability. This shows that investor's disinterest in seeing EPS in investing can increase the company's stock price so that fluctuating EPS does not have an impact on stock returns to be received by investors.

d. Total Asset Turnover (TATO) partially has a significant effect on the stock returns of property and real estate companies listed on the Indonesia Stock Exchange in 2012 to 2017. The ability of the company to optimize all its assets effectively and efficiently can 
The Effect Of Return On Asset (ROA), Debt To Equity Ratio (DER), Earning Per Share (EPS), Total Asset Turnover (TATO) And Exchange Rate On Stock Return Of Property And Real Estate Companies At Indonesia Stock Exchange Period 2012-2017

Sausan, Korawijayanti, Ciptaningtias

bring revenue to the company, so that it can attract interest investors to buy the company's shares. If many investors invest their shares, the company's stock price will increase, so the company's stock returns received by investors will also increase.

e. The Rupiah Exchange Rate partially has a significant effect on the stock returns of property and real estate companies listed on the Indonesia Stock Exchange in 2012 to 2017. The weakening of the rupiah exchange rate against the US dollar can affect the stock returns that will be received by investors. This will make investors prefer investing in dollars rather than investing in shares. If investors no longer invest their shares in these companies, it will cause the stock price to decline so that the stock returns that investors will receive will also decline.

f. Return on Assets (ROA), Debt to Equity Ratio (DER), Earning per Share (EPS), Total Asset Turnover (TATO) and Rupiah Exchange Rates simultaneously affect the stock returns of property and real estate companies listed on the Indonesia Stock Exchange Year 2012 to 2017. Companies that have high ROA will also generate high profits. This will increase the company's stock returns for investors. If the DER is high then this is not good for the company because it can result in a decrease in the company's stock return. If the company has high EPS, the company's ability to generate profits is also high. This can increase the company's stock return. A high level of corporate TATO can also increase the company's stock return because of the company's ability to utilize all its assets efficiently in generating profits. In addition, the weakening of the rupiah against the US dollar can reduce the company's stock return if the company has foreign loans in the form of dollars with a high amount.

\section{REFERENCE}

Aisah, Ayu Nurhayani dan Kastawan Mandala. 2016. Pengaruh Return On Equity, Earning Per Share, Firm Size dan Operating Cash Flow Terhadap Return Saham. E-Jurnal Manajemen Unud. Vol. 5, No. 11. ISSN 2302-8912.

Alipudin, Asep dan Resi Oktaviani. 2016. Pengaruh EPS, ROE, dan DER Terhadap Harga Saham pada Perusahaan Sub Sektor Semen yang Terdaftar di BEI. Jurnal Ilmiah Akuntansi Fakultas Ekonomi. Vol. 2, No. 1. Edisi 1, Hal. 1-22. E-ISSN 2502-4159.

Amrillah, Muhammad Faisal. 2016. Pengaruh Nilai Tukar Rupiah (KURS), Inflasi dan Pertumbuhan Ekonomi terhadap Return Saham pada Perusahaan Perbankan yang Terdaftar di Bursa Efek Indonesia (BEI) periode 2008-2014. Jurnal Valuta. Vol. 2, No. 2. ISSN 2502-1419.

Ang, Robbert. 1997. Buku Pintar Pasar Modal Indonesia. Jakarta: Mediasoft Indonesia.

Anwaar, Maryyam. 2016. Impact of Firms' Performance on Stock Returns (Evidence from Listed Companies of FTSE-100 Index London, UK). Global Journals Inc. (USA). Volume 16, Issue 1, Version 1.0. Online ISSN 2249-4588. Print ISSN 0975-5853.

Ariyanti, Ajeng Ika. 2016. Pengaruh CR, TATO, NPM, dan ROA terhadap Return Saham. Jurnal Ilmu dan Riset Manajemen, Vol. 5, No. 4. ISSN 2461-0593.

Atidhira, Agung Tri dan Andi Ina Yustina. 2017. The Influence of Return on Asset, Debt to Equity Ratio, Earnings per Share, and Company Size on Share Return in Property and Real Estate Companies. Journal of Applied Accounting and Finance. Vol. 1, No. 2, Page 128146. ISSN 2580-1791 (Print). ISSN 2615-8051 (Online).

Bararoh, Tantri. 2015. Analysis of Fundamental Factors, Foreign Exchange and Interest Rate on Stock Return (Studies in Manufacturing Companies Listed on Indonesia Stock Exchange 
The Effect Of Return On Asset (ROA), Debt To Equity Ratio (DER), Earning Per Share (EPS), Total Asset Turnover (TATO) And Exchange Rate On Stock Return Of Property And Real Estate Companies At Indonesia Stock Exchange Period 2012-2017

Sausan, Korawijayanti, Ciptaningtias for 2011-2013 periods. International Journal of Business and Management Invention. ISSN (Online): 2319-8029. ISSN (Print): 2319-801X. Volume 4, Issue 2, PP. 36-42.

Basalama, Ihsan S., Sri Murni dan Jacky S.B. Sumarauw. 2017. Pengaruh Current Ratio, DER Dan ROA Terhadap Return Sham Pada Perusahaan Automotif Dan Komponen Periode 2013 - 2015. Jurnal EMBA. Vol.5, No. 2, Hal. 1793 - 1803. ISSN 2303 - 1174.

Bisara, Chrismas dan Lailatul Amanah. 2015. Pengaruh Kinerja Keuangan Terhadap Return Saham. Jurnal Ilmu dan Riset Akuntansi. Vol. 4, No. 2.

Brigham, Eugene F. dan Joel F. Houston. 2014. Dasar-Dasar Manajemen Keuangan. Buku 1. Edisi 11. Jakarta : Salemba Empat.

Dendawijaya, Lukman. 2003. Manajemen Perbankan, Edisi kedua. Jakarta: Ghalia Indonesia.

Defrizal. 2015. Analisis Pengaruh Rasio Keuangan Terhadap Return Saham. Jurnal Manajemen dan Bisnis. Vol. 6, No. 1, Hal. 22-40. ISSN 2087-0701.

Rahman, Gian Dwi dan Khairunnisa. 2016. Pengaruh Tobin's Q, Inflasi, Suku Bunga, Dan Nilai Tukar Terhadap Return Saham (Studi Pada Perusahaan Manufaktur Yang Terdaftar Di Bursa Efek Indonesia Periode 2011-2014). E-Proceeding of Management. Vol.3, No.1, Hal. 331. ISSN 2355-9357.

Ghozali, Imam. 2013. Aplikasi Analisis Multivariate dengan Program IBM SPSS 19.Semarang: Badan Penerbit Universitas Diponegoro.

Halim, Abdul dan Mamduh M. Hanafi. 2009. Analisis Laporan Keuangan. Edisi Keempat. Yogyakarta: UPP STIM YKPN.

Husnan, Suad. 2005. Dasar-dasar Teori Portofolio dan Analisis Sekuritas. Yogyakarta: Penerbit UPP AMP YKPN.

Indriastuti, Ariyani dan Zumrotun Nafiah. 2017. Pengaruh Volume Perdagangan, Kurs Dan Risiko Pasar Terhadap Return Saham. Jurnal STIE Semarang. Vol. 9, No.1. ISSN 20855656.

Ikatan Akuntan Indonesia (IAI). 2010. PSAK No. 56 Laba Per Saham. Indonesia: IAI.

Jogiyanto, Hartono. 2014. Teori Portofollio dan Analisis Investasi. Edisi Kesepuluh. Yogyakarta: BPEE.

Khan. Wajid. 2013. The Impact of Capital Structure and Financial Performance on Stock Returns "A Case of Pakistan Textile Industry. Middle-East Journal of Scientific Research. 16 (2), 289-295. ISSN 1990-9233.

Korawijayanti, Lardin. 2014. Analisis Perbedaan Pengaruh Faktor-Faktor Fundamental dan Kurs Terhadap Return Saham Antara Perusahaan Pma Dengan Pmdn. JABPI. Vol. 22, No.1. ISSN 1411-687.

Marundha, Amor dan Widarto Racbini. 2014. Debt to Equity Ratio, Pertumbuhan Laba, Pertumbuhan Assets dan Return Saham Perusahaan Property dan Real Estate di Bursa Efek Indonesia. Jurnal Riset Akuntansi dan Perpajakan. Vol. 1, No. 1, Hal. 71-81. ISSN 2339-1545.

Mawardi, Amna. 2018. Pengaruh Nilai Tukar, Tingkat Bunga, Inflasi, dan Jumlah Uang Beredar Terhadap Indeks Harga Saham Sektor Keuangan Di Bursa Efek Indonesia (BEI). Jurnal Ekonomi dan Bisnis. Vol.9, No.1. ISSN 2503-4413.

Mayuni, Ida Ayu Ika dan Gede Suarjaya. 2018. Pengaruh ROA, Firm Size, EPS, Dan PER Terhadap Return Saham Pada Sektor Manufaktur Di BEI. E-Jurnal Akuntansi Universitas Udayana. Vol.7, No.8. ISSN 2302-8912. 
The Effect Of Return On Asset (ROA), Debt To Equity Ratio (DER), Earning Per Share (EPS), Total Asset Turnover (TATO) And Exchange Rate On Stock Return Of Property And Real Estate Companies At Indonesia Stock Exchange Period 2012-2017

Sausan, Korawijayanti, Ciptaningtias

Mulya, Yudhia dan Ririn Turisna. 2017. Pengaruh Kinerja Keuangan Terhadap Return Saham Pada Perusahaan Sub Sektor Otomotif Yang Terdaftar Di Bursa Efek Indonesia. JIMFE (Jurnal Ilmiah Manajemen Fakultas Ekonomi). Vol. 2, No. 1. Edisi 2, Hal. 41-52. E-ISSN 2502-5678.

Munawir. 2014. Analisa Laporan Keuangan. Edisi Keempat. Yogyakarta: Liberty.

Putra, Ferdinan Eka, dan Paulus Kindangen. 2016. Pengaruh ROA,NPM,dan EPS Terhadap Return Saham Perusahaan Makanan dan Minuman yang Terdaftar di BEI Periode 20102014. Vol.4, No.4, Hal. 235-245. ISSN 2303-1174.

Raningsih, Ni Kadek dan I Made Pande Dwiana Putra. 2015. Pengaruh Rasio-Rasio Keuangan dan Ukuran Perusahaan pada Return Saham. E-Jurnal Akuntansi Universitas Udayana. Vol.13, No.2, Hal 582-598. ISSN 2302-8556.

S, Anistia Nurhakim, Irni Yunita dan Aldilla Iradianty. Pengaruh Profitabilitas dan Inflasi Terhadap Return Saham Pada Industri Farmasi yang Terdaftar di BEI Periode 2011 - 2014. E-Proceeding of Management. Vol. 3, No. 1, Hal. 206. ISSN 2355-9357.

Rulandari, N., Rusli, B., Mirna, R., Nurmantu, S., \& Setiawan, M. I. (2018). Valuation of production sharing contract cost recovery vs gross split in earth oil and gas cooperation contracts in Indonesia and the aspect of public service. Journal of Physics: Conference Series, 1114(1), 12132.

Sekaran, Uma. 2006. Metodologi Penelitian Untuk Bisnis. Edisi 4. Buku 1. Jakarta : Salemba Empat.

Septiana, Farda Eka dan Aniek Wahyuati. 2016. Pengaruh Rasio Keuangan Terhadap Return Saham Pada Perusahaan Manufaktur. Jurnal Ilmu dan Riset Manajemen. Vol. 5, No. 1. ISSN 2461-0593.

Sofyan, M. (2019). Faktor-Faktor Yang Mempengaruhi Profitabilitas Bank Perkreditan Rakyat (BPR) di Provinsi Jawa Timur. Jurnal Inspirasi Bisnis Dan Manajemen, 3(1), 63-76. http://dx.doi.org/10.33603/jibm.v3i1.2093.

Sofyan, M. (2019). Analysis Financial Performance Of Rural Banks In Indonesia. International Journal of Economics, Business and Accounting Research (IJEBAR), 3(03). http://dx.doi.org/10.29040/ijebar.v3i03.588.

Sofyan, M. (2016). Sistem Pengendalian Intern Pengelolaan Pajak Restoran Dalam Meningkatkan Pendapatan Asli Daerah (PAD) Kota Bogor. Jurnal Eksekutif, 13(1).

Suriyani, Ni Kadek dan Gede Mertha Sudiartha. 2018. Pengaruh Tingkat Suku Bunga, Inflasi Dan Nilai Tukar Terhadap Return Saham Di Bursa Efek Indonesia. E-Jurnal Akuntansi Universitas Udayana. Vol.7, No.6. ISSN 2302-8912.

Suyati, Sri. 2015. Pengaruh Inflasi,Tingkat Suku Bunga Dan Nilai Tukar Rupiah/Us Dollar Terhadap Return Saham Properti Yang Terdaftar Di Bursa Efek Indonesia. Jurnal Ilmiah Untag Semarang. Vol. 4, No. 3. ISSN 2302- 2752.

Verawaty, Ade Kemala Jaya dan Tita Mandela. 2015. Pengaruh Kinerja Keuangan Terhadap Return Saham Pada Perusahaan Pertambangan Yang Terdaftar di Bursa Efek Indonesia. Jurnal Universitas Bina Darma, Vol. 11, No. 2. ISSN Online 2477-2984. ISSN Cetak 18786579 . 